\title{
IN VITRO SCREENING FOR ACETYLCHOLINESTERASE ENZYME INHIBITION POTENTIAL OF MUTHU PARPAM - THERAPEUTIC LEAD FOR ALZHEIMER'S DISEASE
}

\author{
SABARI GIRIJA ${ }^{1 *}$, GUPTAJ $\mathrm{S}^{2}$, SINEKHA MA ${ }^{3}$, SAKTHIMANIPRIYA L $^{1}$, SHANMUGAPRIYA ${ }^{1}$ \\ ${ }^{1}$ Department of Nanju Maruthuvam, National Institute of Siddha, Chennai, Tamil Nadu, India. ${ }^{2}$ Sri Sairam Siddha Medical College and \\ Research Centre, Chennai, Tamil Nadu, India. ${ }^{3}$ Department of Noinaadal, National Institute of Siddha, Chennai, Tamil Nadu, India. \\ Email: drgirijakrish@gmail.com
}

Received: 27 Apil 2020, Revised and Accepted: 08 June 2020

ABSTRACT

Objective: Siddha system is an ancient traditional system of medicine treats many chronic ailments and neurological disorders. Muthu parpam is one of the herbo marine Siddha drugs which have the indication for neurocognitive dysfunction. The main objective of this current study was to evaluate the acetylcholine esterase (AChE) inhibition of Muthu parpam.

Methods: AChE activity was evaluated using a modified 96-well microplate assay based on Ellman's method. Physostigmine (5, 10, 20, and 40 $\mu$ g/ml) was used as the positive control.

Results: The result of this study clearly indicates that the test drug Muthu Parpam was effective in inhibiting AChE enzyme at the specified concentration dose dependently. Maximum percentage inhibition of about $71.68 \%$ was observed at $500 \mu \mathrm{g} / \mathrm{ml}$ when compared to that of the Physostigmine, a known AChE inhibitor with the maximum inhibition $84.87 \%$ at the concentration of $40 \mu \mathrm{g} / \mathrm{ml}$.

Conclusion: Hence, this preliminary screening has proven the efficacy of Muthu parpam through AChE inhibition potential in the management of Alzheimer disease.

Keywords: Acetylcholine esterase, Muthu parpam, Alzheimer disease, Acetylcholine esterase inhibition, Cognitive function, Siddha.

(C) 2020 The Authors. Published by Innovare Academic Sciences Pvt Ltd. This is an open access article under the CC BY license (http://creativecommons. org/licenses/by/4. 0/) DOI: http://dx.doi.org/10.22159/ajpcr.2020.v13i8.38062

\section{INTRODUCTION}

Alzheimer's disease (AD) is characterized that occur during the formation of amyloid aggregates within the core of neuritic plaque, and therefore, the formation of intraneuronal neurofibrillary tangles within the brain of afflicted individuals [1]. In the human brain, there are two major forms of cholinesterases, namely, acetylcholine esterase (AChE) and butyrylcholinesterase [2]. The foremost remarkable biochemical change in $\mathrm{AD}$ patients may be reduced of ACh levels within the hippocampus and cortex of the brain [3]. ACh is the principal neurotransmitter which functions all told autonomic ganglia and is the only neurochemical that triggers motor division of the somatic systema nervosum. The deterioration of cholinergic neurons within the brain, and therefore, the loss of neurotransmission is the key causes of the decline in cognitive function in patients with AD [4]. In normal cholinergic activity consisting the sequence of release, binding and enzymatic deactivation of ACh by AChE, while abnormal cholinergic activity is characterized by a deficit or short-fall in cholinergic transmissions at synapses and has been attributed to reduced production of ACh or its excess deactivation/hydrolysis by AChE. Therefore, inhibition of AChE, the enzyme liable for the hydrolysis of ACh at the cholinergic synapse, is currently the foremost established approach to treating $\mathrm{AD}$ [5]. Impairment in signal transduction across synapses is the main etiology for cognitive impairment [6,7] and thus regulating the activities of AChE has become a crucial research focus [8].

Synthetic acetyl-cholinesterase inhibitors (AChEIs) include donepezil, rivastigmine, galantamine, and tacrine are commercially available drugs which influence the dynamics of ACh by inhibiting the activity of AChE. These actions taken place on cholinergic receptors of synaptic cells. Due to the side effects of synthetic AChEIs which include gastrointestinal disturbances, moderate effectiveness, high cost and short half-life of AChEIs, there always a need for exploring the character for newer potent and long-lasting AChE inhibitors with minimal side effects [9-11]. There always a need for exploring the character for newer potent and long-lasting AChE inhibitors with minimal side effects. An outsized number of plant species from different parts of the globe are examined for cholinesterase inhibitory activity [8,12].

Traditional medicine is defined as the sum total of the knowledge, skill, and practices based on the theories, beliefs, and experiences indigenous to different cultures, whether explicable or not, used in the maintenance of health as well as in the prevention, diagnosis, improvement, or treatment of physical and mental illness [13]. Siddha system is one of the traditional systems of medicine mainly practiced in Southern India. This is a standard system of drugs mainly practiced within the southern a part of India. As per Siddha literature, Muthu Parpam is the herbo - marine Siddha formulation which has the indication for Marutchi (i.e., confusion and perplexity of mind). Muthu (Pearl) is one in all the nine gems possess the expectorant, styptic, tonic, and spasmodic action $[14,15]$. Hence, this study was an attempt to find out the ACh esterase (AChE) inhibition potential of Muthu Parpam.

\section{METHODS}

The purification process of Muthu [14]

Soak the pearl ( $35 \mathrm{~g}$ ) in sour curd and should be kept under the sunlight for 3 days. Daily morning sour curd should be poured on the pearl. To stay dry, it should be kept under the daylight for 2 days without adding the curd. Repeat this process 2 times and then a pearl should be washed and dry it.

\section{Ingredients [14]}

- $\quad$ Purified Muthu (Pinctada margaritifera) - 1 palam (35 g)

- $\quad$ Notchi (Vitex negundo) - 2 palam (70 g)

- Nilappanai kizhangu (Curculigo orchioides) - 2 palam (70 g) 


\section{Method of preparation}

Thirty-five grams of purified Muthu (pearl) should be soaked in $70 \mathrm{~g}$ of notchi juice for 2 days and then grind it with the notchi juice for 2 days. Then, it should be made into villai (pellets) and dry it in the sunlight. The pellets should be placed in an earthen vessel which should be closed with another vessel and the margin of vessels sealed with seven layered clay cloths and the set up should be dried in sunlight for 1 day. After that, it should be placed in a deep pit and pudam process (calcination process) should be done with 40 cow dung cakes. Then, this same procedure should be repeated with the juice of nilappanai kizhangu and then make it as a fine powder. The final product, the parpam should be stored in the airtight glass container.

\section{Triplicate - 1}

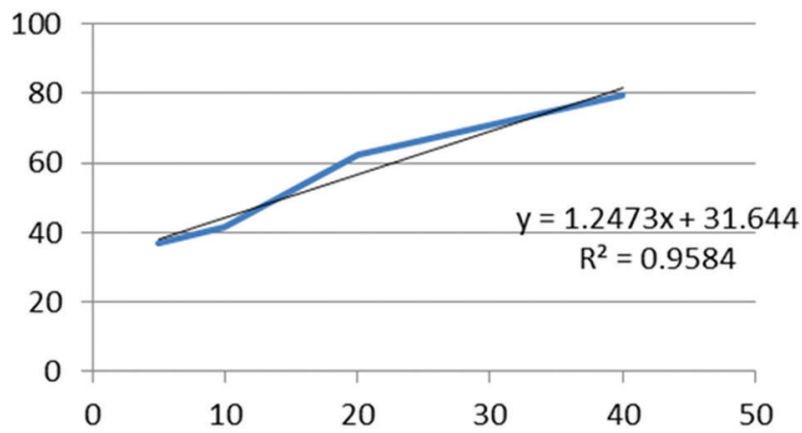

\section{Triplicate -2}

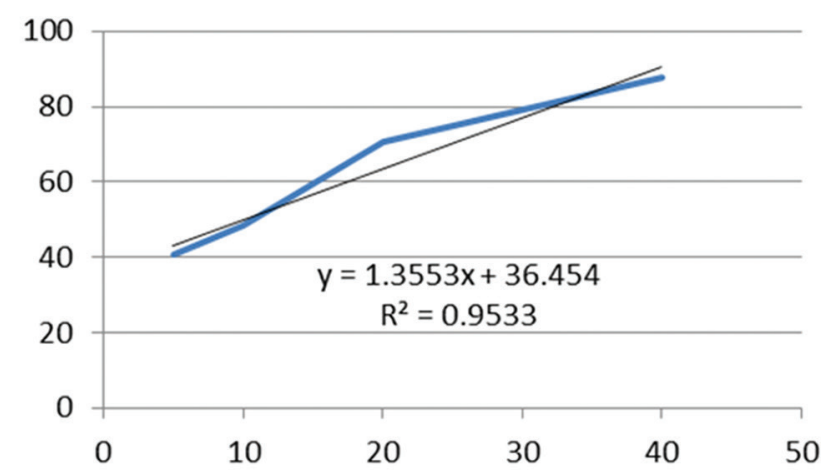

\section{Triplicate -3}

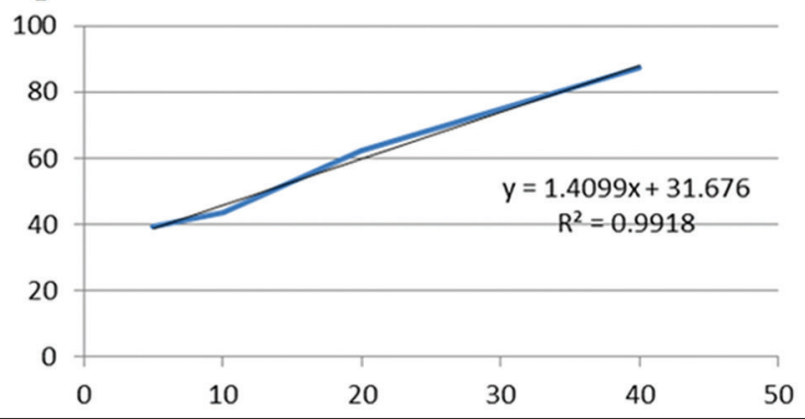

Graph 1: Percentage inhibition of standard - physostigmine on AChE enzyme inhibition assay

Table 1: Percentage inhibition of AChE enzyme by test drug - MP

\begin{tabular}{ll}
\hline $\begin{array}{l}\text { The concentration of MP } \\
\text { in } \boldsymbol{\mu} \mathbf{g} / \mathbf{m l}\end{array}$ & $\begin{array}{l}\text { Percentage inhibition of AChE } \\
\text { enzyme by test drug }\end{array}$ \\
\hline MP 25 & $14.71 \pm 4.24$ \\
MP 50 & $28.75 \pm 3.92$ \\
MP 100 & $36 \pm 3.78$ \\
MP 250 & $48.63 \pm 2.19$ \\
MP 500 & $71.68 \pm 2.38$ \\
\hline
\end{tabular}

Each value represents the mean \pm SD. $n=3$. MP: Muthu Parpam
Indication and adjuvants [16]

- Nirvidam (Asparagus racemosa) [15] - Nithiraiyil undaagum marutchi (Confusion and perplexity of mind during the sleep)

- Water - Maalaikan noi (Night blindness)

- Milk - Pithathaal undaagum veppam (Heat due to pitham)

- Nilathulasi juice - valippu (epilepsy)

- Nilavilaa juice - pitha diseases

- Devadhaaru decoction - Vatha diseases

- Butter - moolam (Piles)

- Vilvam leaf juice - Adhisaaram (diarrhoea)

- Brown sugar - vaanthi (Vomit)

Test drug for analysis

The test drug Muthu Parpam prepared with the above manner was procured from the GMP certified pharmaceutical (Earth India Naturals) company and given for the analysis.

In vitro AChE enzyme inhibition assay - methodology [17]

AChE activity was measured employing a modified 96-well microplate assay supported Ellman's method. Enzyme hydrolyses the substrate acetylthiocholine leading to the merchandise thiocholine which reacts with Ellman's reagent (DTNB) to provide 2-nitrobenzoate5-mercaptothiocholine and 5-thio-2-nitrobenzoate which might be detected at $412 \mathrm{~nm}$. $50 \mathrm{mM}$ Tris- $\mathrm{HCl} \mathrm{pH} 8.0$ was used as a buffer throughout the experiment. AChE enzyme stock solution (518 U/ml) was stored at $-80^{\circ} \mathrm{C}$ and therefore, the enzyme-dilution was done in $0.1 \%$ BSA within the buffer. DTNB was dissolved within the buffer containing $0.1 \mathrm{M} \mathrm{NaCl}$ and $0.02 \mathrm{M} \mathrm{MgCl} 2$. ATCI was dissolved in deionized water. Within the 96-well plates, $100 \mu \mathrm{l}$ of three mM DTNB, $20 \mu \mathrm{l}$ of $0.26 \mathrm{U} / \mathrm{ml}$ of $\mathrm{AChE}$, and $40 \mu \mathrm{l}$ of buffer ( $50 \mathrm{mM}$ tris $\mathrm{pH}$ 8.0), to which $20 \mu \mathrm{l}$ of test drug in various concentrations $(25,50,100,250$, and $500 \mu \mathrm{g} / \mathrm{ml}$ ) dissolved in a buffer containing no more than $10 \%$ methanol was added to the wells. After mixing, the plate was incubated for $15 \mathrm{~min}\left(25^{\circ} \mathrm{C}\right)$. The enzymatic reaction was initiated by the addition of $20 \mu \mathrm{l}$ of $15 \mathrm{mM}$ acetylthiocholine iodide and therefore the hydrolysis of acetylthiocholine was monitored by reading the absorbance every $5 \mathrm{~min}$ for $20 \mathrm{~min}$ at $412 \mathrm{~nm}$. Physostigmine $(5,10,20$, and $40 \mu \mathrm{g} / \mathrm{ml})$ was used because of the positive control. All the reactions were performed in triplicate.

\section{RESULTS AND DISCUSSION}

AChE activity has been shown to be increased within and around amyloid plaques to develop the assembly of amyloid beta-peptides into fibrils and to extend the cytotoxicity of those peptides. The results obtained from the four extracts of Muthu Parpam against AChE enzyme inhibition activity and also the percentage inhibition was evaluated and tabulated (Tables 1 and 2). Muthu parpam showed very potent inhibition $(71.68 \pm 2.38 \%)$ at the concentration of $500 \mu \mathrm{g} / \mathrm{ml}$ in comparison with physostigmine $(84.87 \pm 4.78 \%)$ at the concentration of $40 \mu \mathrm{g} / \mathrm{ml}$ (Graph 1).

Physostigmine was first isolated from Calabar beans (Physostigma venenosum) in 1864 [18] and is an AChE inhibitor [19]. Although physostigmine can cross the blood brain barrier, this drug contains a narrow therapeutic index due to its short half-life and various side effects. The common side effects of physostigmine are hypersalivation, nausea, vomiting, and arrhythmia in arterial blood vessel patient and bradycardia [20]. Some studies have suggested that the AChE inhibitor, rivastigmine could also be fatal [21], while cholinesterase inhibitors

Table 2: Percentage inhibition of AChE enzyme by standard drug

\begin{tabular}{ll}
\hline $\begin{array}{l}\text { The concentration of } \\
\text { physostigmine in } \boldsymbol{\mu g} / \mathbf{m l}\end{array}$ & $\begin{array}{l}\text { Percentage inhibition of AChE } \\
\text { enzyme by std drug }\end{array}$ \\
\hline 5 & $38.87 \pm 1.99$ \\
10 & $44.48 \pm 3.53$ \\
20 & $65.12 \pm 4.64$ \\
40 & $84.87 \pm 4.78$ \\
\hline
\end{tabular}

Each value represents the mean \pm SD. $n=3$ 
remain to be a vital therapeutic tool against AD. AChE inhibitors in contemporary medicines should be undertaken for the treatment to prevent the side effects.

This study revealed that the Muthu Parpam significantly inhibited AChE in a very dose-dependent manner. Notchi ( $V$. negundo) juice employed in the preparation of Muthu Parpam has the pharmacological activity of anxiolytic and anti-amnesic [22,23]. Some pharmacological studies are reported that the Nilappanai kizhangu (C. orchioides) have the anticonvulsant activity and alleviate the cerebral ischemic injury in in vivo and in vitro experimental models [23,24]. Hence, adding these juices additionally enhance the cognitive function of the brain.

\section{CONCLUSION}

Aging is a natural and normal process; it is decaying the body continuously. Inappropriate aging may be preventable through principles suggested by ancient sages (Siddhars) which are called as Noianugavidhi (prevention of diseases). Promoting mental health state is that the need of the hour. Effectiveness of Muthu Parpam in the treatment of $\mathrm{AD}$ was proven through this study on the inhibition potential of acetylcholine choline esterase. It had been a preliminary screening for evaluating the efficacy. Hence, further clinical studies on Muthu Parpam should be necessary to position the footprints within the neurocognitive field.

\section{ACKNOWLEDGMENT}

The author wishes to acknowledge the Noble research solutions, Perambur and Prof. Dr. R. Meenakumari, Director of National Institute of Siddha, Chennai, for their extended support in conducting this research work

\section{AUTHORS' CONTRIBUTION}

The authors, Dr. N. Sabari Girija, Dr. S. Guptaj, and Dr. M. A. Sinekha conceived of the presented idea. The corresponding author prepared the manuscript with the help of Dr. L. Sakthimanipriya. Experimental and manuscript work was supervised by Dr. P. Shanmugapriya. All the authors have equally contributed in preparing this manuscript.

\section{CONFLICTS OF INTEREST}

The authors have declared that they have no conflicts of interest in this study.

\section{REFERENCES}

1. Badami O, Dongr SH, Suresh B. In vitro Antioxidant property of Solanum pseudocapsicum leaf extract. Indian J Pharmacol 2005;37:251-2.

2. Giacobini E. Cholinergic function and Alzheimer's disease. Int J Geriatr Psychiatry 2003;18 Suppl 1:S1-5.

3. DeKosky ST, Harbaugh RE, Schmitt FA, Bakay RA, Chui HC, Knopman DS, et al. Cortical biopsy in Alzheimer's disease: Diagnostic accuracy and neurochemical, neuropathological, and cognitive correlations. Intraventricular bethanecol study group. Ann Neurol
1992;32:625-32.

4. Bartus RT, Dean RL, Beer B, Lippa AS. The cholinergic hypothesis of geriatric memory dysfunction. Science 1982;217:408-17.

5. Sims NR, Bowen DM, Allen SJ, Smith CC, Neary D, Thomas DJ, et al. Presynaptic cholinergic degeneration in patients with dementia. J Neurochem 1983;40:503-9.

6. Brenner GM. Pharmacology. Philadelphia, PA: WB Saunders Company; 2000 .

7. Rahman AU, Choudhary MI. Bioactive natural products as a potential source of new pharmacophores a theory of memory. Pure Appl Chem 2001;73:555-60

8. Oh MH, Houghton PJ, Whang WK, Cho JH. Screening of Korean herbal medicines used to improve cognitive function for anti-cholinesterase activity. Phytomedicine 2004;11:544-8.

9. Melzer D. New drug treatment for Alzheimer's disease: Lessons for healthcare policy. BMJ 1998;316:762-4.

10. Schulz V. Ginkgo extract or cholinesterase inhibitors in patients with dementia: What clinical trial and guidelines fail to consider. Phytomedicine 2003;10 Suppl 4:74-9.

11. Wollen KA. Alzheimer's disease: The pros and cons of pharmaceutical, nutritional, botanical, and stimulatory therapies, with a discussion of treatment strategies from the perspective of patients and practitioners. Altern Med Rev 2010;15:223-44

12. Orhan I, Sener B, Choudhary MI, Khalid A. Acetylcholinesterase and butyrylcholinesterase inhibitory activity of some Turkish medicinal plants. J Ethnopharmacol 2004;91:57-60.

13. Traditional Medicine, Definition, World health Organisation; 2020. Available from: https://www.who.int/traditional-complementaryintegrative-medicine/about/en

14. Thiyagarajan R. Gunapadam Thadhu-Jeeva Vaguppu. $8^{\text {th }}$ ed., Vol. 2, 3. Chennai: Directorate of Indian medicine and Homeopathy; 2013. p. 500, 501.

15. Pillai TV. Tamil-English Dictionary. Vol. 5, 6. Chennai: The Research Institute of Siddhar's Science; 1931. p. 717

16. Thiyagarajan R. Theran Yamaga Venbaa. $1^{\text {st }}$ ed., Vol. 2. Chennai: Booma Devi Printers; 1997. p.105.

17. Ellman GL, Courtney KD, Andres V, Featherstone RM. A new and rapid colorimetric determination of acetylcholinesterase activity. Biochem Pharmacol 1961;7:88-95.

18. Thal LJ, Fuld PA, Masur DM, Sharpless NS. Oral physostigmine and lecithin improve memory in Alzheimer disease. Ann Neurol 1983;13:491-6.

19. Arens AM, Kearney T. Correction to: Adverse effects of physostigmine. J Med Toxicol 2019;15:310.

20. Ali TB, Schleret TR, Reilly BM, Chen WY, Abagyan R. Adverse effects of cholinesterase inhibitors in dementia, according to the pharmacovigilance databases of the United-States and Canada. PLoS One 2015;10:e0144337.

21. Gupta RK, Tandon VR. Antinociceptive activity of Vitex negundo Linn leaf extract Indian. J Physiol Pharmacol 2005;49:163-70.

22. Kanwal A, Mehla J, Kuncha MS, Naidu VG. Anti-amnesic activity of Vitex negundo in scopolamine induced amnesia in rats. Pharmacol Pharm 2010;1:1-8.

23. Chen QS, Chen WQ, Yang SY. Pharmacologic study of Curculigo orchioides gaertn. Zhongguo Zhong Yao Za Zhi 1989;14:618-20, 640.

24. Jiang W, Fu F, Tian J, Zhu H, Hou J. Curculigoside A attenuates experimental cerebral ischemia injury in vitro and vivo. Neuroscience 2011;192:572-9. 